\title{
THE LAWS OF INNKEEPERS
}

-For Hotels, Motels, Restaurants, and Clubs 



\title{
THE LAWS OF INNKEEPERS
}

-For Hotels, Motels, Restaurants, and Clubs

\author{
THIRD EDITION
}

\section{JOHN E. H. SHERRY}

Cornell University Press 
Copyright $(\mathbb{C}$ 1972, 1981, 1993 by Cornell University

All rights reserved. Except for brief quotations in a review, this book, or parts thereof, must not be reproduced in any form without permission in writing from the publisher. For information address Cornell University Press, Sage House, 512 East State Street, Ithaca, New York 14850.

First edition, by John H. Sherry, published 1972 by Cornell University Press.

Revised edition, by John E. H. Sherry, published 1981 by Cornell University Press.

Third edition, by John E. H. Sherry, published 1993 by Cornell University Press.

International Standard Book Number 0-8014-2508-5

Library of Congress Catalog Card Number 92-30561

Printed in the United States of America

Librarians: Library of Congress cataloging information

appears on the last page of the book.

(2) The paper in this book meets the minimum requirements

of the American National Standard for Information Sciences-

Permanence of Paper for Printed Library Materials, ANSI Z39.48-1984. 